Available Online : https://proceeding.researchsynergypress.com/index.php/cset/index

RSF Conference Series: Engineering and Technology

ISSN 2809-6843 (Online) | 2809-6878 (Print)

Volume 1 Number 1 (2021): 590-596

\title{
Evaluation of Florpyrauxifen-Benzyl Herbicides for Control on Common Weeds in Transplanted Rice
}

\author{
Abdul Rizal1, Dyah Arbiwati² \\ 1Department of Agroteknologi, Universitas Pembangunan Nasional "Veteran" Yogyakarta \\ 2Departement of Soil Science, Universitas Pembangunan Nasional “Veteran” Yogyakarta
}

\begin{abstract}
The research to test the effectiveness of the herbicide Florpyrauxifen-Benzylin in controlling weeds in rice was carried out in Sragen, Central Java. March to August 2021. The herbicides tested are: T1) Florpyrauxifen-Benzyl $400 \mathrm{ml} / \mathrm{ha}$, T2) Florpyrauxifen-Benzyl $600 \mathrm{ml} / \mathrm{ha}$, T3) Florpyrauxifen-Benzyl $800 \mathrm{ml} / \mathrm{ha}$, T4) Florpyrauxifen-Benzyl $1000 \mathrm{ml} / \mathrm{ha}$, T5) Aryloxyphenoxy propionate $800 \mathrm{ml} / \mathrm{ha}$, T6) Penoxsulam $800 \mathrm{ml} / \mathrm{ha}$, T7) Natrium Byspiribac $300 \mathrm{ml} / \mathrm{ha}$ T8) Metsulfuron Methyl, T9) Hand Weeding and T10) Untreated. The herbicides were applied with the help of a knapsack sprayer by using a T-jet nozzle. The calibration of the knapsack sprayer was done by spraying on a nonexperimental area. The volume of water used for spray was $300 \mathrm{~L}$ per ha. The results showed that the application of florpyrauxifen-benzyl in various doses did not show toxicity to rice plants. application of florpyrauxifen-benzyl starting at a dose of $600 \mathrm{ml} / \mathrm{ha}$ had the same effectiveness in controlling weeds as companion herbicides. At the end of the study, E. crus-galli and L. chinensis still seemed to dominate all plots in all herbicide applications.
\end{abstract}

Keywords: Florpyrauxifen-Benzyl, herbicides, weeds, transplanted rice

This is an open access article under the CC-BY-NC license

\section{INTRODUCTION}

Herbicides are widely used by farmers around the world because they are an effective weed control tactic, require less labor, and reduce operating costs. In weed control there is a tendency for farmers to use herbicides continuously without paying attention to the selection of the right type and dose. one of the impacts of herbicide use is weed persistence to herbicide and evolution (Somerville, 2018). Kniss (2018) reported that the development of weed resistance due to herbicides was recorded at around five cases per year from 1990 to 2015. Heap (2020) reports that there are 92 species of herbicide resistance spread across 70 countries. Weed management practices to prevent the occurrence of herbicide resistance can be done by alternately giving herbicides with different active ingredients

Florpyrauxifen benzyl (trademark as Rinskor) is a broad-spectrum herbicide for controlling grass, broadleaf, and sedge weeds in rice (Corteva Agriscience., 2019). According to the HRAC O/WSSA including group 4. The second member of the synthetic auxin chemotype, arylpicolinate. Arylpicolinate exhibits new and different characteristics in terms of usage rates, spectrum, weed symptoms, environmental fate, and molecular interactions compared to other auxin chemotypes (Byron et al., 2019). Florpyrauxifenbenzyl (Rinskor ${ }^{\mathrm{TM}}$ Active) is an herbicide currently being developed to control rice weeds (Epp et al. 2016). As a new herbicide, testing should be carried out for the herbicide used as an alternative to herbicide selection.

The purpose of this study was to evaluate the dose of the herbicide Florpyrauxifen-Benzylin which had the same or greater level of control with comparison herbicides.

Corresponding author: abdul.rizal@upnyk.ac.id 


\section{MATERIAL AND METHODS}

The treatments were arranged in a completely randomized block design in Sragen, Central Java. march to August 2021. The herbicides tested are: T1) Florpyrauxifen-Benzyl $400 \mathrm{ml} / \mathrm{ha}$, T2) Florpyrauxifen-Benzyl $600 \mathrm{ml} / \mathrm{ha}, \mathrm{T} 3$ ) Florpyrauxifen-Benzyl $800 \mathrm{ml} / \mathrm{ha}, \mathrm{T} 4)$ Florpyrauxifen-Benzyl 1000ml/ha, T5) Aryloxyphenoxy propionate $800 \mathrm{ml} / \mathrm{ha}$, T6) Penoxsulam $800 \mathrm{ml} / \mathrm{ha}$, T7) Natrium Byspiribac $300 \mathrm{ml} / \mathrm{ha}$, T8) Metsulfuron Methyl, T9) Hand Weeding and T10) Untreated. The herbicides were applied with the help of a knapsack sprayer by using a T-jet nozzle. The calibration of the knapsack sprayer was done by spraying on a non-experimental area. The volume of water used for spray was $300 \mathrm{~L}$ per ha., Target pest: a common weed of rice. The research parameters are (1) phytotoxicity (visual) of rice at 3, 7, 14, dan 28 Day After Application (DAA) herbicide). Visible phytotoxicity on rice seedling by $0-10$ scale. $0=$ no visible phytotoxicity, 1 = very light spots, 2 = very light lesions, $3=$ very visible foliar phytotoxicity, $4=$ leaf yellowing or whiting, $5=$ leaf burning or blight, $6=>25 \%$ foliar injury, $7=>50 \%$ foliar injury, $8=>90 \%$ foliar injury, 9= severely seedling damage but not dead, 10 = totally dead (2) Weed control per species (\% visual biomass reduction vs control) at 14, 42, dan 56 DAA, use formula Abbot. Abbot Formula \%

Control $=\left(\frac{\mathrm{N}_{U T}-\mathrm{N}_{\mathrm{T}}}{\mathrm{N}_{\mathrm{UT}}}\right) \mathrm{X} 100 \% \mathrm{~N}_{\mathrm{UT}}=$ Number of weeds in Untreated plot, $\mathrm{N}_{\mathrm{T}}=$ Number of weeds in Treated plot. (3) Some Dominant Ratio at 56 DAA.

\section{RESULTS AND DISCUSSION}

The results showed that the weeds growing in the untreated plots were E. cruss-galli, L.chinensis, a weed belonging to the Poaceae family (grasses), F. miliace, C.iria, C. difformis were plant species that belonging to the family Cyperaceae and S. zeylanica, M vaginalis, Ludwigia Sp. is a broadleaf species. Important weeds and their distribution in the south and south Asia, their presence can reduce yields.

\section{Phytotoxicity in rice}

Application of herbicide Florpyrauxifen-Benzyl did not show phytotoxicity until the highest dose. Bisbpiripac herbicide application showed low phytotoxicity, $1=$ very light spots, 2 = very light lesions at 3 DAA to 7 DAA. And gradually normal at 14 DAA. Other comparison herbicide applications did not show herbicide phytotoxicity in rice

\section{Weed control}

The application of Florpyrauxifen-Benzyl $400 \mathrm{ml} /$ ha has not been able to control E. crus-galli, with a control percentage of $77 \%$ to $90 \%$. while at higher doses at 14 DAA and 26 DAA, the percentage of control was above $90 \%$ and decreased at the age of 42 to 56 DAA. The percentage of control of FlorpyrauxifenBenzyl $600 \mathrm{ml} / \mathrm{ha}, 800 \mathrm{ml} / \mathrm{ha}$, and $1000 \mathrm{ml} /$ ha were above 90\%. The application of a comparison herbicide was effective in controlling E. crus-galii with a control percentage above $90 \%$ (fig. 1a)

L. chinensis was known to be present at 28 DAA. in all treatment plots. Application of FlorpyrauxifenBenzyl doses of $400 \mathrm{ml} / \mathrm{ha}, 28 \mathrm{DAA}, 42 \mathrm{DAA}$, and 56 DAA. provide percent control $82 \%$, 90\% and 86 percent. The application of comparison herbicides and hand weeding was effective in controlling $\mathrm{L}$. chonensis up to 42 DAA, at 56 DAA with the percentage of weed control above $90 \%$ (fig. $1 \mathrm{~b}$ ). The application of Florpyrauxifen-Benzyl at a dose of $400 \mathrm{ml} /$ ha has not been able to effectively control E. crus-galli and L. chinensis which are grass weeds.

Figures $1 \mathrm{c}$ and $1 \mathrm{~d}$. shows the percentage of weed control of the sedges group. F. milliacea began to be identified at 28 DAA while C. iria at 42 DAA. Application of Florpyrauxifen-Benzyl was effective in 
controlling $F$, millicea, and $C$. difformis starting at a dose of $400 \mathrm{ml} / \mathrm{ha}$. Application of aryloxyphenoxy propionate $800 \mathrm{ml} /$ ha gave a comparable Herbicide control percentage to control $80 \%$ to $85 \%$.

The application of the herbicide Florpyrauxifen-Benzyl at various doses showed that the percentage of weed control was below $90 \%$ as well as the comparison herbicide, 5 controls of all tested herbicides gave control levels of Ludwigia Sp and Spenochlea sp weeds above 90 percent (fig2 and fig2b). FlorpyrauxifenBenzyl and other herbicides tested were effective in controlling weeds Spenochlea sp and M. vaginalis (fig. $2 \mathrm{c}$ and $2 \mathrm{~d}$ ) the percentage of weeds tested were above 90 persen.

Florpyrauxifen-Benzyl (Rinskor ${ }^{\mathrm{TM}}$ active) can be a new alternative for weed control and different from other synthetic auxin herbicides. Rinskor is a post-emergence herbicide in rice plants. Florpyrauxifenbenzyl is a new active ingredient from the arylpicolinate herbicide family (Epp et al. 2016). The synthetic auxin, florpyrauxifen-benzyl showed activity in grasses and broadleaf weeds in rice (Miller and Norsworthy 2018). Therefore, florpyrauxifen-benzyl is a new management option for controlling ALS, ACCase, PSII, and synthetic auxin-resistant broadleaf weed and grass species (Epp et al. 2016).

Bispyribac-sodium is a broad-spectrum post-emergence herbicide, mainly controlling Echinochloa crusgalli; Applications carried out at the fourth leaf stage to tiller stage showed good plant compatibility with direct seed rice. The mode of action of bispyribac-sodium consists in inhibiting the biosynthesis of branched amino acids. This compound presents a good eco-toxicological profile; very suitable for application to rice. Bispyribac sodium inhibits the plant enzyme acetolactate synthase (ALS) which in turn inhibits the production of the amino acids valine, leucine, and isoleucine in plants (Tranel \& Wright 2002)

\section{Dominant summed Ratio (SDR) Weeds}

Table 1 shows that E. cruss-galli and L. chinensis were the two dominant weeds in all treatment plots of weed application. However, the application of florpyrauxifen-benzyl and comparison herbicides showed control percentages above 90 percent (Figure 1 and Figure 2). E. cruss-galli and L. chinensis were effectively controlled manually even though during vegetative growth they had almost the same morphology as rice plants.

The use of herbicides to control E. crus-galli and L. chinensis is widely practiced, in the early stages of herbicides it can control weeds but at later stages, there are still E. crus-galli and L. chinensis even though the population is below the threshold.

\section{CONCLUSION}

The results showed that the application of florpyrauxifen-benzyl in various doses did not show toxicity to rice. Application of florpyrauxifen-benzyl starting at a dose of $600 \mathrm{ml} /$ ha has the same effectiveness as a companion herbicide. At the end of the study (56 DAA) E. crus-galli and L. chinensis dominated all experimental plots.

\section{Acknowledgment}

This research was funded by LPPM UPN “Veteran” Yogyakarta in 2021. The author would like to thank 


\section{REFERENCE}

Corteva Agriscience (2019). Rinskor Collects the 2018 AGROW Award for the Best New Crop Protection. https://www.proquest.com/docview/2226445221/70BF98CC832B4EA5PQ/2?accountid=20 7111. Accessed: Mart. 5, 2021

Heap IM (2019) International survey of herbicide resistant weeds. http://www.weedscience.org/in.asp. Accessed: Agust. 5, 2021

Miller MR, Norsworthy JK (2018) Florpyrauxifen-benzyl weed control spectrum and tank-mix compatibility with other herbicides commonly used in rice. Weed Technology 32:319-32

Montgomery GB, Bond JA, Golden BR, Gore J, Edwards HM, Eubank TW, Walker TW (2015) Utilization of saflufenacil in a Clearfield $®$ rice (Oryza sativa) system. Weed Technol 29:255-262

Somerville, Gayle J; Powles, Stephen B; Walsh, Michael J; Renton, Michael (2018) Modeling the Impact of Harvest Weed Seed Control on Herbicide-Resistance Evolution. Weed Science; Lawrence 66, 395-403

Tranel, P. J., and Wright, T. R. 2002. Resistance of weeds to ALS-inhibiting herbicides: What have we learned? Weed Science, 50: 700-712. 


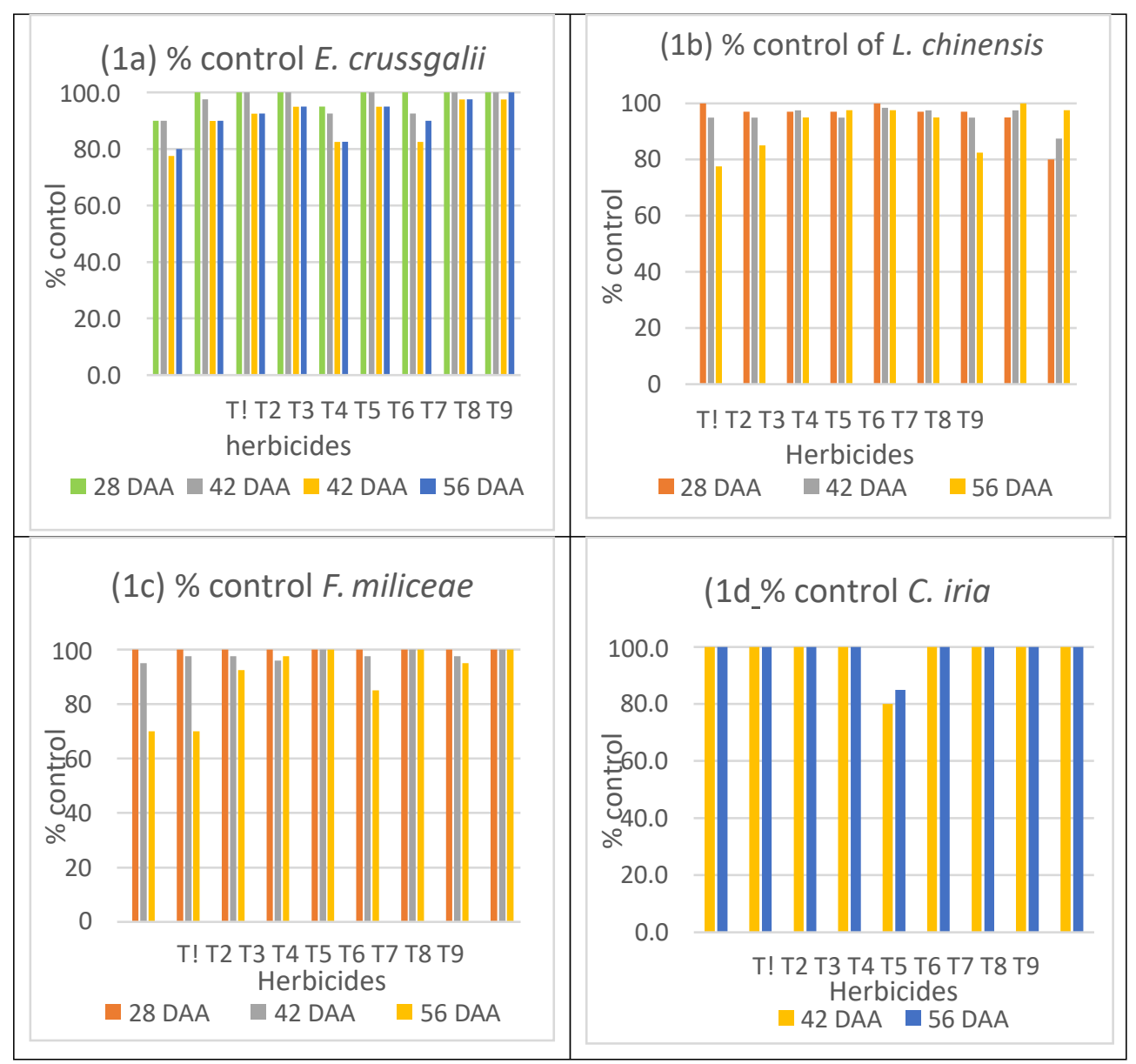

Note: : T1) Florpyrauxifen-Benzyl 400 ml/ha, T2) Florpyrauxifen-Benzyl 600 ml/ha, T3) FlorpyrauxifenBenzyl $800 \mathrm{ml} / \mathrm{ha}$, T4) Florpyrauxifen-Benzyl 1000ml/ha, T5) aryloxyphenoxy propionate $800 \mathrm{ml} / \mathrm{ha}$, T6) Penoxsulam $800 \mathrm{ml} / \mathrm{ha}$, T7) Natrium Byspiribac $300 \mathrm{ml} / \mathrm{ha}$ T8) Metsulfuron Methyl, T9) Hand Weeding

Figure 1. Percentage control of E. Crusgalii, L. chinensis, F. molliacea and C. iria due to various herbicide applications. 
Evaluation of Florpyrauxifen-Benzyl Herbicides for Control on Common Weeds in Transplanted Rice Abdul Rizal, Dyah Arbiwati

Note: :

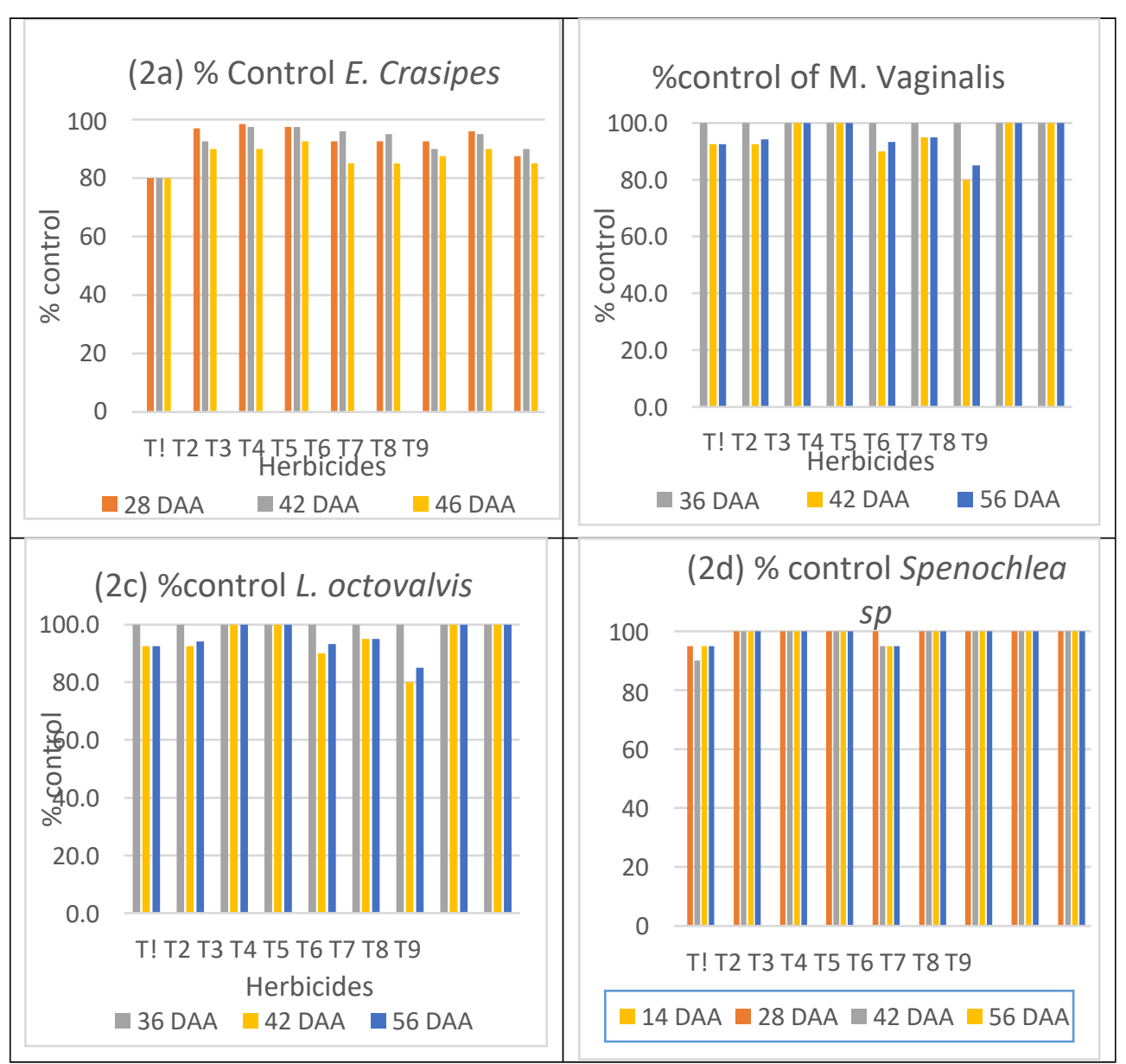

Florpyrauxifen-Benzyl $400 \mathrm{ml} / \mathrm{ha}$, T2) Florpyrauxifen-Benzyl $600 \mathrm{ml} / \mathrm{ha}$,T3) Florpyrauxifen-Benzyl $800 \mathrm{ml} / \mathrm{ha}$, T4) Florpyrauxifen-Benzyl 1000ml/ha, T5) aryloxyphenoxy propionate $800 \mathrm{ml} / \mathrm{ha}$, T6) Penoxsulam $800 \mathrm{ml} / \mathrm{ha}$,

T7) Natrium Byspiribac 300 ml/ha T8) Metsulfuron Methyl, T9I) Hand Weeding

Figue 2. Percentage of control of E. gracipes, M vaginalis, L. octovalvis and Spenochlea sp. due to various herbicide applications. 
Table 1. Dominant summed Ratio (SDR) Weeds

\begin{tabular}{|c|c|c|c|c|c|c|c|c|c|}
\hline \multirow{2}{*}{ Tret } & \multirow{2}{*}{ Treatment } & \multicolumn{8}{|c|}{ Some Ratio Dominance (\%) } \\
\hline & & 1) & 2) & 3) & 4) & 5) & 6) & 7) & 8) \\
\hline $\mathrm{T} 1$ & Florpyrauxifen-Benzylr $400 \mathrm{ml} / \mathrm{ha}$ & $\begin{array}{r}35 \\
4\end{array}$ & 30,4 & 8,3 & 0 & 4,7 & 12,2 & 5 & 4 \\
\hline $\mathrm{T} 2$ & Florpyrauxifen-Benzyl $600 \mathrm{ml} / \mathrm{ha}$ & $\begin{array}{r}30, \\
8\end{array}$ & 30 & 2,5 & 0 & $\begin{array}{r}22 \\
4\end{array}$ & 14,3 & 0 & 0 \\
\hline T3 & Florpyrauxifen-Benzyl 8000 ml/ha & $\begin{array}{r}54, \\
2\end{array}$ & 30,4 & $\begin{array}{r}15 \\
4\end{array}$ & 0 & 0 & 0 & 0 & 0 \\
\hline $\mathrm{T} 4$ & Florpyrauxifen-Benzyl 1000 ml/ha & $\begin{array}{r}52, \\
2\end{array}$ & 42,2 & 5,6 & 0 & $\begin{array}{r}13 \\
4\end{array}$ & 0 & 0 & 0 \\
\hline T5 & aryloxyphenoxy propionate $800 \mathrm{ml} / \mathrm{ha}$ & $\begin{array}{r}25 \\
7\end{array}$ & 27,3 & 5,6 & 0 & $\begin{array}{r}13 \\
6\end{array}$ & 13,4 & 5,2 & 9,2 \\
\hline T6 & Penoxsulam $750 \mathrm{ml} / \mathrm{ha}$ & $\begin{array}{r}25 \\
6\end{array}$ & 35,9 & $\begin{array}{r}15 \\
2\end{array}$ & 0 & $\begin{array}{r}13 \\
1\end{array}$ & 10,2 & 0 & 0 \\
\hline $\mathrm{T} 7$ & Natrium Byspiribac $300 \mathrm{ml} / \mathrm{ha}$ & $\begin{array}{r}28, \\
3\end{array}$ & 37,6 & 0 & 4,2 & $\begin{array}{r}12, \\
1\end{array}$ & 17,8 & 0 & \\
\hline $\mathrm{T} 8$ & Metsulfuron Methyl $700 \mathrm{ml} / \mathrm{ha}$ & $\begin{array}{r}32 \\
4\end{array}$ & 30,6 & 0 & 14,3 & $\begin{array}{r}11, \\
6\end{array}$ & 11,1 & 0 & 0 \\
\hline T9 & Hand Weeding & $\begin{array}{r}46 \\
7\end{array}$ & 53,3 & 0 & 0 & 0 & 0 & 0 & \\
\hline $\mathrm{T} 10$ & UNTREATED & $\begin{array}{r}15 \\
4\end{array}$ & 18,3 & 7,2 & 6,5 & $\begin{array}{r}15 \\
1\end{array}$ & 22,2 & 10,1 & 5,2 \\
\hline
\end{tabular}

Note : 1) E.cruss-galli, ,2) L.chinensis, 3), F. miliace, 4) C.iria, 5). Ludwigia Sp. 6) E.crasspes. 7) S. zeylanica 8) M aginalis 